\title{
Quantitative Cellular Evaluation and Anatomical Organization of the External Region of Different Genetic Materials and Maturation Stages of Tomato Processing
}

\author{
Darlene Ana de Paula Vieira ${ }^{1}$ \\ https://orcid.org/0000-0001-8040-4934 \\ Márcio Caliari ${ }^{2 *}$ \\ https://orcid.org/0000-0002-0877-8250
}

\section{Eli Regina Barboza de Souza ${ }^{3}$}

https://orcid.org/0000-0001-6225-6122

\author{
Divina Aparecida Anunciação Vilhalva ${ }^{4}$ \\ https://orcid.org/0000-0001-5278-9590
}

\author{
Manoel Soares Soares Júnior ${ }^{5}$ \\ https://orcid.org/0000-0001-8728-4592
}

${ }^{1}$ Federal Institute of Goiás, Department of Academic Areas, Inhumas, Goiás, Brazil; 2,3,4,5Goiás Federal University, School of Agronomy, Goiânia, Goiás, Brazil.

Received: 2019.06.01; Accepted: 2020.03.19.

*Correspondence: macaliari@ufg.br (M.C); Tel.: +55-6235211611xx (F.L.), darlene.vieira@ifg.edu.br (D.A.P.V).

HIGHLIGHTS

- Anatomy of the tomato epidermis for determining the quality at the point of harvest.

- Evaluation of the anatomy of tomato fruits for processing.

- Use of microphotographs with the aid of the ImageJ software.

\begin{abstract}
The effect of the anatomical structure of tomato skin may be significant for quality determination at the harvest point, but the definitions of cells that constitute the skin of fleshy fruits, such as tomato, are still unclear, providing contradictory descriptions. The aim of this study was to evaluate the epidermal tissue of different genetic materials of tomato processing (IT761, U2006, TC2736, CVR2909 and F3060) and maturation stage, in order to compare and choose genetic materials with morphological characteristics of the epidermis region more appropriate for the bulk transport. Micrographs were used for cell measurements using the Image $\mathrm{J}$ software. Cuticle undergoes thickening during fruit growth, and reduction in full maturation. Genetic materials presenting fruits with thicker cuticle at the harvest stage (CVR2909, F3060 and IT761) were more advantageous due to their mechanical resistance. Cuticle deposition ends before full fruit maturation, resulting in a decrease in the amount of cutin per surface unit, consequently decreasing cuticle thickness in the ripe fruit. The characteristics observed in the tomato fruit mesocarp clearly showed the disruption of the cell wall during the fourth maturation stage related to loss of fruit firmness. Among the new genetic materials, F3060 has a greater potential to become cultivated for industrialization due to its morphological characteristics, such as elevated cuticle thickness and high values for width, height, perimeter and area of epidermal cells in full maturation stage, which make it suitable for bulk transport.
\end{abstract}

Keywords: cuticle; epidermis; cell size; digital image. 


\section{INTRODUCTION}

Tomato is an important vegetable in the human diet and has special nutritional properties that help in the prevention of cancer, cardiovascular degenerative diseases and cataract, and also improves the immune system [1]. Tomato fruits develop from the ovary, and are anatomically divided into five parts: exocarp, mesocarp, endocarp, seed and locular tissues [2]. After fertilization of ovules, the walls of this organ become the pericarp, which comprises most of the fruit and surrounds the locules containing placenta and seeds [3]. The cellular structure of fruits is usually related in studies on fruit size and shape, mechanical and sensory properties, and can be described by the size, shape and spatial organization of cells within tissues. In berries such as tomatoes, the cell structure can vary with type and location within the tissue, for example, the distance from the epidermis, pedicel or vascular bundles [4].

The cell structure of plant tissues is generally investigated using microscopy to quantify the size and shape of cells [5]. This approach leads to several problems regarding the field-of-view size in the microscopic acquisition because fruit cells are generally large.

Berries are characterized by a protective exocarp or epicarp, mesocarp and fleshy endocarp. Exocarp plays a fundamental role in fruit growth and development, in particular, high cell division and metabolic activity, and this tissue also plays an important role in fruit quality and in fruit / environment interaction [6]. One of the obstacles still to be overcome in this type of fruit is the precise interpretation of the exocarp and its function in fruit biology, and the difficulty in defining the boundary between epicarp, mesocarp and endocarp $[7,8]$.

The coating and filling tissues of fruits are of fundamental importance for quality determination at the harvest point. The exocarp consists of a well-defined layer of collenchymatous tissues, while the mesocarp consists of thin-walled cells with numerous intercellular spaces ${ }^{2}$. Coating tissues determine the external appearance, color, brightness and limit the internal and external environments of the product, being important after harvest [9], because coating tissues directly influence the exchange of gases, such as water vapor, oxygen and carbon dioxide, resistance to insect and pathogen attack, and resistance to mechanical injuries during handling, as well as filling tissues [10]. The latter, located more internally, store large volumes of water, minerals and carbohydrates, important for diet [11]. Both tissues vary widely among genetic materials and are responsible for the determination of fruit volume and maintenance of important characteristics for market such as texture, soluble solids content and aroma [12].

Cuticle is a lipid extracellular membrane that covers the outer surface covering the primary surface of aerial organs of all terrestrial plants, including fruits, acting as a true interface between the plant organ and the environment [13], and although it is central for limiting non-stomatal water losses, it plays several roles, and is an effective barrier against pests and pathogens [14], and also plays a key role in fruit development through the establishment of boundaries between young organs [15].

Skin and pulp firmness are the most relevant properties in the characterization of tomato processing and are related to maturation rate and fruit susceptibility to mechanical damage during harvesting, transportation and processing. Ripe fruits are often soft and break easily due to lack of firmness. Fruit growth and maturation are complex processes involving several metabolic alterations, so fruit maturation is a qualitative measure, difficult to be determined [16]. Firmness is a mechanical property inversely proportional to fruit maturation and therefore can be used as maturation indicator [17].

There is a great variety of tomato processing, and it is important to know the anatomy of fruits, as there is lack of information on the subject. In the present study, photomicrographs analysis and statistical tools (Anova factorial and Tukey test) were used in order to evaluate the epidermal tissue of different genetic materials of tomato processing (IT761, U2006, TC2736, CVR2909 and F3060) at different maturation stages, in order to compare and choose genetic materials with morphological characteristics of the epidermis region more appropriate for the bulk transport.

\section{MATERIAL AND METHODS}

\section{Material}

Fruits from tomato processing (IT761, U2006, TC2736, CVR2909 and F3060), the first two commercial cultivars (IT761 and U2006) and the others experimental genetic materials ((TC2736, CVR2909, F3060)), used in the present study were donated by the experimental unit of Cargill, located at the municipality of Hidrolândia, Goiás, Brazil. 


\section{Experimental design}

Completely randomized design was used, with $5 \times 4$ factorial scheme, five genetics materials (IT761, U2006, TC2736, CVR2909 and F3060) and four maturation stage (green, green-yellow, yellow-red, red), and four replicates, totaling 80 experimental units (eighty samples with 10 tomatoes each). Five fruits were evaluated for each experimental unit. Sampled fruits were always the third and fourth of the third plant bunch, because they present higher uniformity.

\section{Cultivation, harvest and sample preparation}

Soil analyses were carried out on October before crop implantation in soil with $\mathrm{pH}$ of 5.8 , aluminum of $0.0 \mathrm{cmolc} \mathrm{dm}-3$, calcium of $3.1 \mathrm{cmolc} \mathrm{dm}-3$, magnesium of $1.0 \mathrm{cmolc} \mathrm{dm}-3$, potassium of $0.30 \mathrm{mg} \mathrm{dm}-3$, phosphorus of $53.1 \mathrm{mg} \mathrm{dm}-3$, cation exchange capacity (CEC) of $6.57 \mathrm{~g} \mathrm{dm}-3$, organic matter of 17.4 dag $\mathrm{dm} 3$, sand, silt and clay percentages of $300.0 \mathrm{~g} \mathrm{~kg}-1,80.0 \mathrm{~g} \mathrm{~kg}-1,620.0 \mathrm{~g} \mathrm{~kg}-1$ in the $0-20 \mathrm{~cm}$ layer, and in the $20-40 \mathrm{~cm}$ layer, $\mathrm{pH}$ of 5.4 , aluminum of $0.0 \mathrm{cmolc} \mathrm{dm}-3$, calcium of $1.6 \mathrm{cmolc} \mathrm{dm}-3$, magnesium of 0.5 cmolc dm-3, potassium of $0.23 \mathrm{mg} \mathrm{dm}-3$, phosphorus of $27.3 \mathrm{mg} \mathrm{dm}-3$, CEC of $5.26 \mathrm{~g} \mathrm{dm}-3$, organic matter of $19.0 \mathrm{~g} \mathrm{dm}-3$, sand, silt and clay percentages of $280.0 \mathrm{~g} \mathrm{~kg}-1,75.0 \mathrm{~g} \mathrm{~kg}-1 ; 650.0 \mathrm{~g} \mathrm{~kg}-1$, respectively.

Soil fertility and acidity correction was performed with dolomitic limestone ( $3 \mathrm{t}$ ha-1), and soil was prepared with a cross harrow. Mineral fertilization of 4-39-16 NPK formulation (1,300 kg ha-1) was distributed in plants. Secor (0.8 L ha-1) and Boral $(0.1 \mathrm{~L}$ ha- 1$)$ herbicides were also used. Sprinkler irrigations occurred on April 7, 23 and 28; on May 4, 8, 15, and 18 and 24, June 3, 10, and 18, totaling $147.60 \mathrm{~mm}$, being uniform in all plots. Seedling production occurred in greenhouses using coconut fiber as substrate. Foliar fertilization was carried out, as well as weekly sprays with fungicides and insecticides. Seedling transplanting was carried out on March 15. Mospilan was sprayed for the control of white fly and Bravonil fungicide was used for the control of septoriosis. Manual harvesting occurred from June to September. Fruits were collected at four maturation stages: fully green, yellow-green, yellow-red, red or full maturation. Tomatoes were packed in lowdensity polyethylene bags (LDPE), coded, and transported to the Laboratory of Processing of Plant Origin Products, School of Agronomy - Federal University of Goiás, Goiânia, GO. Fruits were then selected for appearance, absence of injury, rot and maturation stage, submitted to manual washing, and sanitization with $150 \mathrm{mg} \mathrm{L-1}$ sodium hypochlorite solution for $20 \mathrm{~min}$ and naturally dried.

\section{Anatomical characteristics of fruits}

Samples of $1.0 \mathrm{~g}$ of tomato pulp, $1 \times 1 \times 0.5 \mathrm{~cm}$ (length $\mathrm{x}$ width $\mathrm{x}$ height) were collected from the equatorial area of intact fruits using a scalpel, and immediately fixed in $70 \mathrm{~g} 100 \mathrm{~g}-1$ FAA (formaldehyde at $40 \mathrm{~g} 100 \mathrm{~g}$ $1,5 \mathrm{~mL}$; ethyl alcohol at $70 \mathrm{~g} 100 \mathrm{~g}-1,90 \mathrm{~mL}$, glacial acetic acid, $5 \mathrm{~mL}$ ) for $72 \mathrm{~h}$, and subsequently stored in glass vials containing $70 \mathrm{~g} 100 \mathrm{~g}-1$ alcohol according to technique described by Johansen [18]. Sections (cross-sectional and longitudinal) were performed by hand with the aid of a razor blade and stained with astra blue and basic fuchsin dyes. Sections were mounted on semipermanent slides with $50 \mathrm{~g} 100 \mathrm{~g}-1$ glycerin solution. Analysis and photographic recording were performed in optical microscopy (Leica Microsystems, LAD EZ, Wetzlar, Germany). In the histochemical characterization, sections were submitted to reagents sudan III to determine the presence of lipids, cutin, and suberin lugol to detect starch. For the study of fruit surface, sections were stained with safranin (alcoholic solution). Anatomical analyses were performed at the Laboratory of Plant Anatomy of the Department of Botany, Biological Sciences Institute - Federal University of Goiás. Skin measurements were performed on microphotographs at $40 \mathrm{X}$ magnification using the Image software, public domain software developed by National Institutes of Health, and created by W. S. Rasband [19]. Cuticle thickness, width, height, area and skin cell perimeter were automatically measured after scale calibration. Thirty readings were obtained using the freehand selection tools of the Image.

\section{Analysis of results}

Data obtained in anatomical analyses were submitted to analysis of variance (Anova factorial), using the Assistat 7.7 Beta software, and means were compared by the Tukey test $(p<0.05)$. Before performing analysis of variance, normality data and variance homogeneity were tested by applying the Shapiro-Wilk and Bartlett tests, respectively.

\section{RESULTS}

The growth and maturation of tomato processing are complex, development processes that involve several metabolic alterations, representing, therefore, a good system of anatomical study. The epicarp or 
skin of fruits includes the cuticle and the epidermis, and is of fundamental importance for fruit firmness. In the photomicrographic analyses carried out on tomatoes at all maturation stages, it was observed that the cuticle extends between anticline walls of epidermal cells, presenting flange. Epidermal isodiametric cells are below the cuticle, after parenchyma cells, which increase in size as they move away from the epidermis (Figure 1).

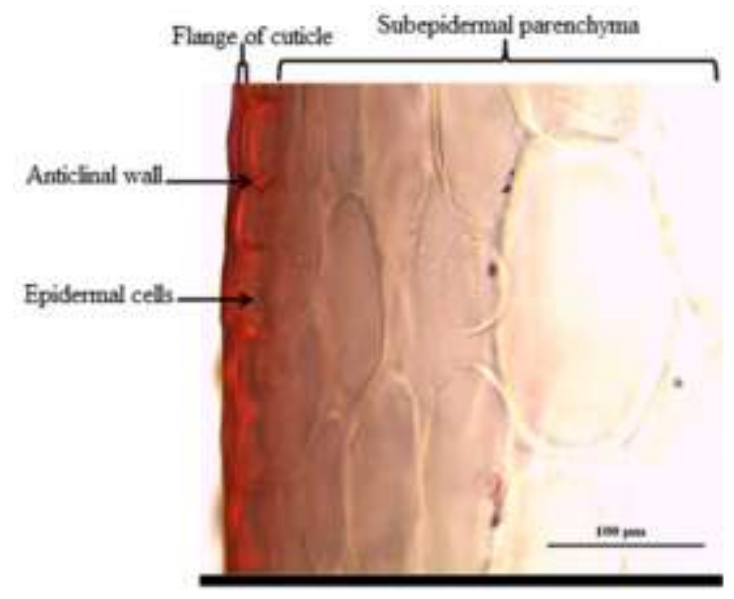

Figure 1. Cross-section of tomato processing fruits (Solanum lycopersicum) (green maturation stage), treated with reagent Sudan III, highlighting cuticle with flange, epidermis and subepidermal parenchyma.

The effects of the maturation stage, genetic material, and maturation stage $\mathrm{x}$ genetic material interaction were significant $(p<0.05)$ in relation to cuticle thickness, according to the factorial Anova. Cuticle thickness of genetic materials varied at all maturation stages, and was $91.54 \%$ in the first maturation stage (green fruit); the highest value was verified for F3060, and the lowest for CVR2909 and IT761, and the other genetic materials presented intermediate values. The coefficient of variation $(\mathrm{CV})$ value for cuticle thickness of the different genetic materials at each fruit maturation stage ranged from 17.3 to $22.8 \%$, being highest at red stage (Table 1).

Table1. Cuticle thickness $(\mu \mathrm{m})$ of tomato processing (Solanum lycopersicum) at different maturation stages. Goiânia, GO, Brazil.

\begin{tabular}{lllll}
\hline Genetic material & Green & Green-yellow & Yellow-red & Red \\
\hline IT761 & $7,1^{\mathrm{Bbc}} \pm 1,1$ & $10,0^{\mathrm{Ab}} \pm 1,2$ & $10,0^{\mathrm{Aa}} \pm 1,3$ & $6,8^{\mathrm{Bab}} \pm 1,7$ \\
U2006 & $7,6^{\mathrm{Ab}} \pm 1,7$ & $6,5^{\mathrm{AB}} \pm 1,1$ & $5,8^{\mathrm{Bb}} \pm 1,6$ & $5,3^{\mathrm{Bbc}} \pm 0,9$ \\
TC2736 & $6,2^{\mathrm{Bbc} \pm 1,0}$ & $8,5^{\mathrm{Ab}} \pm 1,3$ & $5,1^{\mathrm{BCb}} \pm 1,0$ & 5,0 \\
CVR2909 & $5,7^{\mathrm{Bc}} \pm 0,8$ & $5,2^{\mathrm{BC}} \pm 0,4$ & $8,5^{\mathrm{Aa}} \pm 0,9$ & 7,8 \\
F3060 & $10,9^{\mathrm{ABa}} \pm 1,7$ & $13,2^{\mathrm{Aa}} \pm 2,6$ & $9,2^{\mathrm{BC}} \pm 1,9$ & $7,2^{\mathrm{Ca}} \pm 1,7$ \\
\hline CV $^{2}$ & 17,5 & 17,3 & 17,8 & 22,8 \\
\hline
\end{tabular}

${ }^{1}$ Means followed by different lowercase letters in the same column, and upper case letters on the same row differ from each other by the Tukey test $(P<0.05)$; 2 Variation Coefficient $(\%)$.

The effects of maturation stage and genetic material $x$ maturation stage interaction were not significant ( $p<0.05)$ for the width of epidermal cells $(p=0.051$ and $p=0.056$, respectively), while the effect of genetic material was significant $(p<0.01)$. The width of epidermal cells varied among maturation stages from 23.7 $\mu \mathrm{m}$ to $69.0 \mu \mathrm{m}(190.85 \%)$ at the first maturation stage of fruits. The CV value for epidermal cells width of the different genetic materials at each fruit maturation stage ranged from 17.3 to $22.8 \%$, being highest at green stage and lowest at red stage (Table 2). 
Table 2. Epidermal cells width $(\mu \mathrm{m})$ of tomato processing (Solanum lycopersicum) at different maturation stages. Goiânia, GO, Brazil.

\begin{tabular}{lllll}
\hline Genetic materials & Green & Green-yellow & Yellow-red & Red \\
\hline IT761 & $26,8^{\mathrm{Bb}} \pm 2,0$ & $29,3^{\mathrm{Bb}} \pm 2,3$ & $28,6^{\mathrm{Bb}} \pm 2,4$ & $39,5^{\mathrm{Aa}} \pm 2,1$ \\
U2006 & $38,8^{\mathrm{ab}} \pm 2,3$ & $28,0^{\circ} \pm 3,0$ & $23,9^{\mathrm{b}} \pm 2,1$ & $31,9^{\mathrm{D}} \pm 3,2$ \\
TC2736 & $25,5^{\mathrm{Bb}} \pm 1,8$ & $28,0^{\mathrm{Bb}} \pm 2,2$ & $28,7^{\mathrm{Bb}} \pm 2,5$ & $36,4^{\mathrm{Aab}} \pm 2,0$ \\
CVR2909 & $23,7^{\mathrm{Bb}} \pm 1,4$ & $31,1^{\mathrm{Aab}} \pm 1,7$ & $31,0^{\mathrm{Ab}} \pm 1,2$ & $32,8^{\mathrm{Aab}} \pm 2,1$ \\
F3060 & $69,0^{\mathrm{Aa}} \pm 32,7$ & $45,5^{\mathrm{Aa}} \pm 38,0$ & $51,4^{\mathrm{Aa}} \pm 21,4$ & $37,5^{\mathrm{Aab}} \pm 14,8$ \\
\hline CV $^{2}$ & 74,2 & 68,6 & 40,7 & 31,3
\end{tabular}

${ }^{1}$ Means followed by different lowercase letters in the same column and upper case in the same row differ by the Tukey test $(\mathrm{P}<0.05) ;{ }^{2}$ Variation Coefficient $(\%)$.

The effect of maturation stage was not significant $(p=0.057)$ probability due to the epidermal cells height, while the genetic material $x$ maturation stage interaction and the genetic materials effect were significant $(p$ $<0.01$ ). The CV value for epidermal cells height of the different genetic materials at each fruit maturation stage ranged from 16.1 to $74.2 \%$, being highest at green stage and lowest at red stage. The epidermal cells height as a function of maturation stages, varied significantly among genetic materials (from $15.5 \mu \mathrm{m}$ to 45.6 $\mu \mathrm{m})(193.68 \%)$, both values obtained at the first maturation stage of fruits (green fruit). F3060 had the highest epidermal cell height value, while CVR2909, TC2736 and IT761 the lowest, and U2006 did not differ ( $p$ > 0.05) from the others (Table 3).

Table 3. Epidermal cells height $(\mu \mathrm{m})$ of tomato processing (Solanum lycopersicum) at different maturation stages. Goiânia, GO, Brazil.

\begin{tabular}{lllll}
\hline Genetic material & Green & Green-yellow & Yellow-red & Red \\
\hline IT761 & $17,9^{\mathrm{Bb}} \pm 3,4$ & $17,5^{\mathrm{Bb}} \pm 3,9$ & $21,1^{\mathrm{Ab}} \pm 3,7$ & $20,9^{\mathrm{Aab}} \pm 3,6$ \\
U2006 & $26,0^{\mathrm{Aab}} \pm 2,6$ & $20,3^{\mathrm{Bb}} \pm 3,5$ & $20,8^{\mathrm{B}} \pm 3,2$ & $23,6^{\mathrm{Aab}} \pm 3,0$ \\
TC2736 & $16,5^{\mathrm{Bb}} \pm 3,2$ & $23,1^{\mathrm{Aab}} \pm 3,9$ & $23,6^{\mathrm{Aab}} \pm 3,3$ & $22,6^{\mathrm{Aab}} \pm 3,4$ \\
CVR2909 & $15,5^{\mathrm{Bb}} \pm 3,9$ & $19,2^{\mathrm{Ab}} \pm 4,3$ & $20,6^{\mathrm{Ab}} \pm 4,5$ & $15,5^{\mathrm{Bb}} \pm 7,7$ \\
F3060 & $45,6^{\mathrm{Aa}} \pm 5,4$ & $44,7^{\mathrm{Aa}} \pm 2,7$ & $33,7^{\mathrm{Aa}} \pm 3,4$ & $28,8^{\mathrm{Aa}} \pm 8,4$ \\
\hline CV $^{2}$ & 74,2 & 38,7 & 47,6 & 16,1 \\
\hline
\end{tabular}

${ }_{1}^{1}$ Means followed by different lowercase letters in the same column and upper case in the same row differ by the Tukey test $(\mathrm{P}<0.05) ;{ }^{2}$ Variation Coefficient $(\%)$.

At the first maturation stage (green fruit), it measured between $66.6 \mu \mathrm{m}$ and $132.4 \mu \mathrm{m}$, with variation of 98.94\%, and F3060 presented the highest epidermal cell perimeter value, not differing ( $p>0.05)$ from U2006 (Table 4). At the second stage (green-yellow fruit) the epidermal cell perimeter of continued highest for F3060, while TC2736 showed intermediate value, not differing $(p>0.05)$ from the others. At the third stage, F3060 also obtained the highest cell perimeter value, and at the fourth stage, the highest value was observed for IT761 and F3060, and the lowest for TC2736 and U2006. For IT761, the highest epidermal cell perimeter value was observed at the red stage, and there was no significant difference from the others.

Table 4. Epidermal cells perimeter $(\mu \mathrm{m})$ of tomato processing (Solanum lycopersicum) at different maturation stages. Goiânia, GO, Brazil.

\begin{tabular}{lllll}
\hline Genetic material & Green & Green-yellow & Yellow-red & Red \\
\hline IT761 & $78,5^{\mathrm{Bb}} \pm 8,7$ & $82,5^{\mathrm{Bb}} \pm 9,9$ & $84,5^{\mathrm{Bb}} \pm 7,0$ & $108,5^{\mathrm{Aa}} \pm 10,4$ \\
U2006 & $89,5^{\mathrm{ABab}} \pm 10,8$ & $84,0^{\mathrm{ABb}} \pm 9,4$ & $79,3^{\mathrm{Bb}} \pm 11,6$ & $96,3^{\mathrm{Aab}} \pm 7,1$ \\
TC2736 & $72,0^{\mathrm{Cb}} \pm 7,2$ & $89,1^{\mathrm{Bab}} \pm 9,0$ & $87,4^{\mathrm{Bb}} \pm 6,6$ & $99,2^{\mathrm{Aab}} \pm 7,2$ \\
CVR2909 & $66,6^{\mathrm{Bb}} \pm 7,1$ & $84,4^{\mathrm{Ab}} \pm 9,7$ & $87,3^{\mathrm{Ab}} \pm 10,5$ & $83,5^{\mathrm{Ab}} \pm 16,1$ \\
F3060 & $132,4^{\mathrm{Aa}} \pm 7,5$ & $120,8^{A a} \pm 6,7$ & $123,7^{\mathrm{Aa}} \pm 4,5$ & $108,3^{\mathrm{Aa}} \pm 5,4$ \\
\hline CV $^{2}$ & 38,7 & 30,8 & 21,9 & 12,0 \\
\hline
\end{tabular}

${ }_{1}^{1}$ Means followed by different lowercase letters in the same column and upper case in the same row differ by the Tukey test $(\mathrm{P}<0.05) ;{ }^{2}$ Variation Coefficient $(\%)$.

The CV value for epidermal cells area of the different genetic materials at each fruit maturation stage ranged from 17.0 to $23.3 \%$, being highest at green stage and lowest at red stage (Table 5). At the green stage, F3060 presented the highest epidermal cell area value, not differing from U2006 and IT761, while the lowest values were observed for CVR2909 and TC2736. 
Table 5. Epidermal cell area $(\mu \mathrm{m})$ of tomato processing (Solanum lycopersicum) at different maturation stages. Goiânia, GO, Brazil.

\begin{tabular}{lllll}
\hline Genetic material & Green & Green-yellow & Yellow-red & Red \\
\hline IT761 & $409,4^{\mathrm{Bab}} \pm 93,8$ & $419,4^{\mathrm{Bb}} \pm 89,14$ & $487,6^{\mathrm{Bb}} \pm 83,9$ & $678,0^{\mathrm{Aa}} \pm 91,8$ \\
U2006 & $434,2^{\mathrm{Bab}} \pm 73,7$ & $456,5^{\mathrm{Bab}} \pm 78,22$ & $401,2^{\mathrm{BC}} \pm 67,5$ & $586,7^{\mathrm{Aa}} \pm 100,3$ \\
TC2736 & $336,7^{\mathrm{Cb}} \pm 48,3$ & $538,9^{\mathrm{Bab}} \pm 84,09$ & $544,7^{\mathrm{Bb}} \pm 76,1$ & $643,6^{\mathrm{Aa}} \pm 84,0$ \\
CVR2909 & $288,8^{\mathrm{C}} \mathrm{C} \pm 56,4$ & $466,3^{\mathrm{ABab}} \pm 93,46$ & $511,8^{\mathrm{Abc}} \pm 91,0$ & $397,5^{\mathrm{BCb}} \pm 125,0$ \\
F3060 & $492,7^{\mathrm{Ba}} \pm 148,2$ & $568,1^{\mathrm{ABa}} \pm 161,8$ & $686,5^{\mathrm{Aa}} \pm 129,4$ & $685,7^{\mathrm{Aa}} \pm 103,7$ \\
\hline CV $^{2}$ & 23,3 & 21,6 & 17,5 & 17,0 \\
\hline
\end{tabular}

${ }^{1}$ Means followed by different lowercase letters in the same column and upper case in the same row differ by the Tukey test $(\mathrm{P}<0.05) ;^{2}$ Variation Coefficient $(\%)$.

Cross sections, stained with astra blue and basic fuchsin and test with sudan III, show the of tomato processing cuticle and the epidermis, and below them, the hypodermis and part of the mesoderm (Figure 2A to $\mathrm{H}$ ).
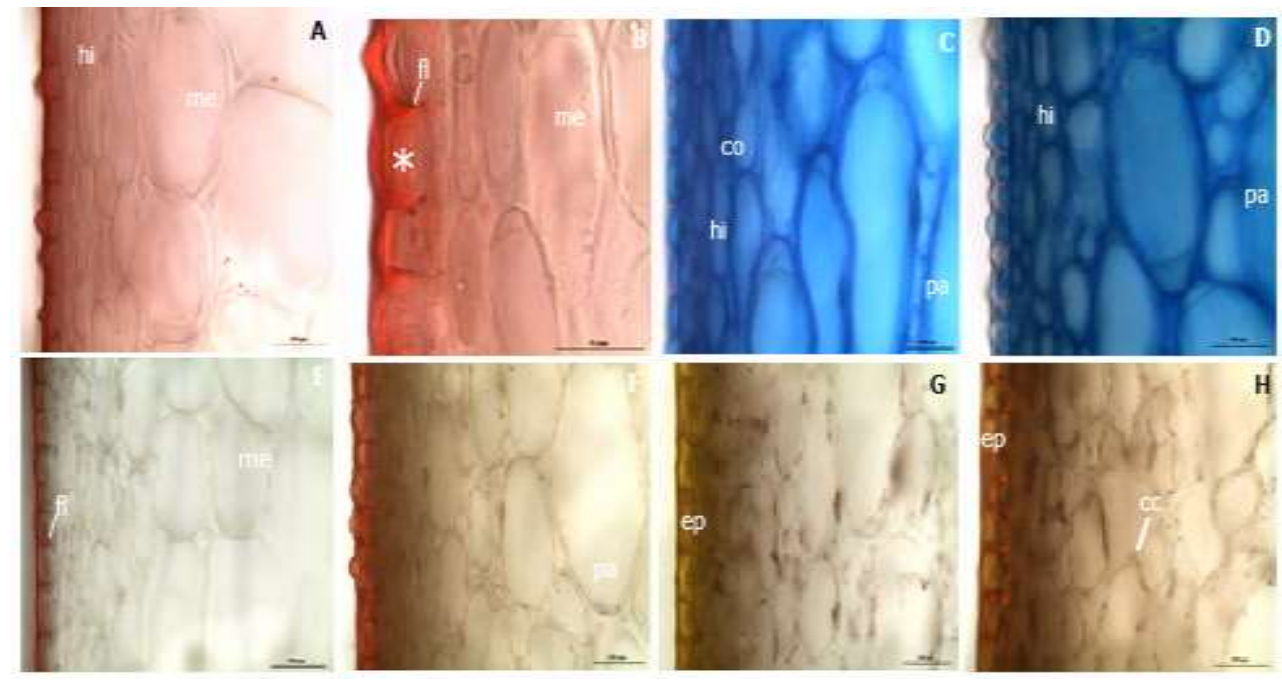

Figure 2. Cross sections, after test with Sudan III and staining with Astra Blue and Fuchsin of the following tomato (Solanum lycopersicum) genetic materials: CVR2909 (A, B and C) ( $1^{\text {st }}$ and $2^{\text {nd }}$ maturation stages, respectively); F3060 (D, E, F and G) (1 $1^{\text {st }}, 2^{\text {nd }}$ and $3^{\text {rd }}$ maturation stages, respectively); and U2006 $(H)\left(4^{\text {th }}\right.$ maturation stage). Cross-sectional details $(\mathrm{fl}=$ flange, $\mathrm{me}=$ mesocarp, $\mathrm{co}=$ colenchyma, $\mathrm{pa}=$ parenchyma, $\mathrm{hi}=$ hypodermis, $\mathrm{ep}=$ epidermis, $\mathrm{cc}=$ collapsed cell).

Figure 3D, E, F, G, H and I show (asterisks) starch granules, which are synthesized during fruit development, and the younger the fruit, the higher the starch content, which accumulates in the form of granules in cells closest to the endocarp (asterisk) (Figure 3E). Of the five genetic materials analyzed, U2006, Figure 3D, E and F, was probably the youngest of all because it presented higher starch content and was the only one to present starch in the second maturation stage analyzed (Figure 3F). 


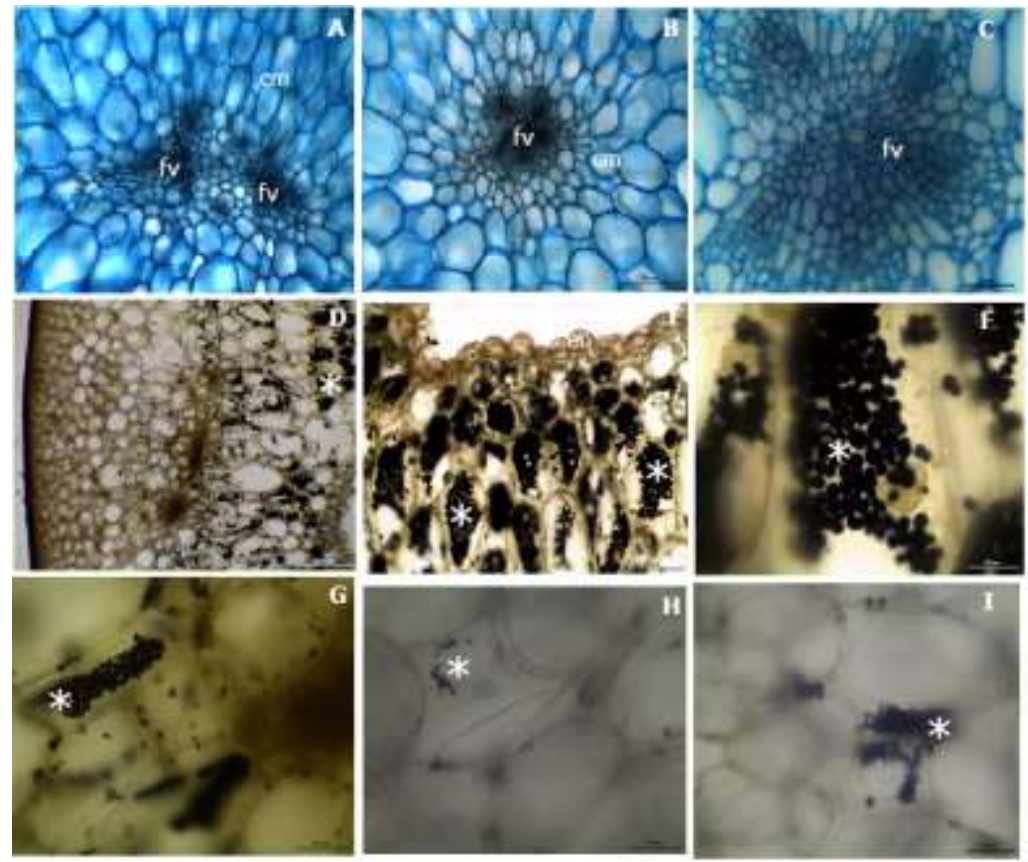

Figure 3. Cross sections stained with Astra Blue and Basic Fuchsin, and reaction with lugol test of the following tomato (Solanum lycopersicum) genetic materials: TC2909 (A), F3060 (B and C) vascular bundles, U2006 (D, E, F and G), F3060 (H and I) starch granules. Details of cross sections $\left({ }^{*}=\right.$ starch granules; $f v=$ vascular bundles; $\mathrm{cm}=$ mesocarp layer around the beam; en = endoderm).

\section{DISCUSSION}

For CVR2909, F3060 and IT761 (an interesting characteristic for industry), and the lowest value was verified for TC2736 and U2006. In the second maturation stage (yellow-green fruit), cuticle thickness varied 153.84\%, being also higher value for F3060 than CVR2909 and U2006, with intermediate value for IT761 and TC2736. At this stage, IT761 and TC2736 underwent cuticle thickening $(40.67 \%$ and $36.99 \%$, respectively). At the third stage (yellow-red fruit), the highest cuticle thickness value was observed for IT761, F3060 and CVR2909, and the lowest for TC2736 and U2006. At this stage, cuticle thickness remained the same as the previous stage for IT761 and U2006, increased for CVR2909 (64.53\%), and decreased for TC2736 and $\mathrm{F} 3060$ (65.30\% and $43.84 \%$, respectively). At the fourth stage (red fruit), the variation of this characteristic among genetic materials was $46.97 \%$, and the highest values were found.

Cuticle thickness value of IT761 was highest at green-yellow and red-yellow stages and smallest for those at green and red stages; for U2006 cuticle thickness was highest at the green maturation stage, and smallest at the yellow-red and red stages, and intermediate at the yellow-green stage; for TC2736 the highest cuticle thickness was observed at the green-yellow stage, followed by the green stage and the lowest in the red stage. At the yellow-red stage, cuticle thickness did not differ between green and red stages. Cuticle thickness value of CVR2909 was highest at yellow-red and red maturation stages, and smallest at green and yellow-green maturation stages. For F3060, the highest cuticle thickness was found in the yellow-green stage and the lowest in the red stages, and the green stage did not differ from yellow-green to yellow-red nor from red-yellow to red stages.

Saladié and coauthors [20] found cuticle thickness measuring 12, 11, 8, 9 and $7.8 \mu \mathrm{m}$ for ripe tomato, values well above those found in this research for fruits at the same maturation stage; but different genetic material have different cuticle thicknesses. The increase in cuticle thickness of fruits in this research did not present linear behavior, not corroborating results found by Bargel and Neinhuis [21], who reported that the biosynthesis of cuticle components declined with maturation.

Cuticle thickness data may be important for understanding fruit firmness. During maturation, many fruits, including tomato, undergo degradation of cell wall components, with cuticle thickness significantly decreasing from immature fruits to full maturation fruits [22], a fact verified in most genetic materials analyzed in this research, except for CRV2909. Differences related to fruit resistance could be explained by the fact that some genetic materials have more or less thick cuticle $(7.3$ and $5.0 \mu \mathrm{m})$ at the ideal maturation stage for harvest.

Cuticle is synthesized by the epidermis forming a cover, being the first barrier against the biotic and abiotic conditions in which the fruit develops [23], and also plays a fundamental role in skin development, in water loss control, fruit integrity, firmness and resistance to various disturbances [13]. According to Dvir and 
coauthors [24], tomato fruits have no stomata or lenticels, being covered by a cuticle that effectively acts in the prevention of dehydration.

The main function attributed to cuticle is to minimize water loss, with consequent maintenance of fruit turgescence and firmness, also limiting the loss of substances from internal tissues, protecting against physical, chemical and biological injuries, also providing support to maintain fruit integrity. The preservation of all these functions requires the maintenance of the structural integrity throughout the cuticle extension during fruit development [25].

Post-harvest water loss results from fruit transpiration and diffusion through the cuticle. Although the water potential gradient from inside to outside of the fruit varies according to temperature and relative air humidity, and this variation results from a combination of fruit maturation, environmental conditions and genetic factors [26]. Therefore, the thicker the cuticle at the harvest stage, the more advantageous for the fruit, with lowest post-harvest losses.

Some studies address cuticle biosynthesis during fruit development, mainly from the morphological or quantitative point of view. Cuticle deposition probably terminates early during the development of apples and oranges before the maturation process, and often, before the fruit reaches its maximum size, resulting in a decrease in the amount of cuticle per surface unit, and therefore, cuticle thickness in the ripe fruit $[27,28]$. This fact was also observed in most tomato genetic materials evaluated in the present study. However, Kosma and coauthors [29] reported that in mutant tomatoes, a continuous increase of cuticular waxes (cutin monomers) was observed during fruit development. This was not verified in this study because, in general, there was an increase followed by a decrease in cuticle thickness.

At the green stage, F3060 showed the greatest width of epidermal cells, while the lowest values were observed for CVR2909 and TC2736, and U2006 presented intermediate value. At the second stage (greenyellow fruit), epidermal cell width value was highest for F3060, lowest for U2006, TC2736 and IT761, while CVR 2909 presented intermediate value, not differing from the others. At the third stage, F3060 also obtained the highest cell width value, and the other genetic materials showed smaller values.

At the fourth stage, IT761 showed the highest epidermal cell width, U2006 presented the lowest, and intermediate values were found in the other genetic materials, not differing from each other, nor from the others already mentioned. Comparing maturation stages, IT761 had the highest epidermal cell width value at the red stage, and the other stages did not differ among themselves; for U2006 and F3060, maturation stages were not significant ( $p>0.05)$, while for TC2736, the largest epidermal cell width value was verified at the red stage and for CVR2909, the lowest value was observed at the green stage.

The quality of fruits is closely related to the structure of the skin, especially epidermis that forms a barrier between internal and external environments. Konarska [30], studying three apple maturation stages, verified for the first stage, epidermal cell width of $13.1 \mu \mathrm{m}$ (21 days after anthesis), at the second stage $22.8 \mu \mathrm{m}$ (preclimacteric) and at the third stage $26.3 \mu \mathrm{m}$ (after harvest), and also observed an increase in the width of these cells throughout fruit development and maturation. However, the present study showed linear increase in the epidermal cells width at different maturation stages only for TC2736 and CVR2909.

At the second and third stages the epidermal cell height was higher for F3060 than for IT761, CVR2909 and U2006, while TC2736 did not differed ( $p>0.05)$ from the others. At the fourth stage, the highest value was also observed for F3060, and the lowest for CVR2909, and the others did not differ among themselves nor from those already mentioned. Comparing maturation stages for IT761, the highest epidermal cell height values were observed at red-yellow and red maturation stages; for U2006, at the green stage, while for TC2736, the lowest value was observed at the green stage. For CVR2909, the highest epidermal cell height value was obtained at yellow-red and yellow-green stages, while for F3060, no difference in relation to this characteristic was found. According to Hammami and Rapoport [8], anatomical measurement provides a means to precisely examine the epidermis cell dimensions, which can contribute with valuable information about the cellular patterns in this region. Thus, this pattern was observed in this study for each genetic material evaluated at different maturation stages.

Comparing maturation stages and genetic materials, differences were observed in the epidermal cell perimeter, according to ANOVA factorial. The CV value for epidermal cells perimeter of the different genetic materials at each fruit maturation stage ranged from 12.0 to $38.7 \%$, being highest at green stage and lowest at red stage.

For U2006, the highest epidermal cell perimeter value was also verified at the red stage, which did not differ from fruits at green and yellow-green stages. For TC2736, as in previous ones, the highest perimeter value occurred at the red stage, not differing from tomatoes at yellow-green and red-yellow stages. For CVR2909, the smallest epidermal cell perimeter was found at the green stage, while for F3060, maturation stages did not affect epidermal cell perimeter. 
Casado (2006) studied the anatomy of table tomato fruits at green-ripe and ripe maturation stages and observed that at the ripe stage, epidermal cells increase in length and slightly decrease in width, which increases perimeter, and accompanied by a change in their morphology, epidermal cells become flatter. In this research, this change was also observed, mainly at the full maturation stage. F3060 presents larger cells than the others genetic materials. According to Bargel and Neinhuis [21], during tomato growth and maturation, the epidermis morphology is subject to considerable changes. According to these authors, cuticle was the most important structural component for the integrity of ripe tomato. For Cao and coauthors [31], the epidermis biomechanics is mainly affected by size, number and arrangement of subepidermal cells. In this sense, fruits with thicker cuticle would be more viable for bulk transport.

The epidermal cell area ranged from $492.74 \mu \mathrm{m} 2$ to $288.82 \mu \mathrm{m} 2(70.60 \%)$ during the first maturation stage.

At the green-yellow stage, variation of $35.45 \%$ in the epidermal cell area was observed, and the highest value was verified for F3060, which did not differ ( $p>0.05)$ from TC2736, CVR2909 and U2006. At the yellowred stage, variation was $71.10 \%$, and $\mathrm{F} 3060$ also showed the highest epidermal cell area value. At the red stage, the smallest epidermal cell area was verified for CVR2909. The area of epidermal cells changed according to genetic material, maturation stage and interaction between both. For IT761, U2006 and TC2736, the largest epidermal cell area was verified at the red stage. For CV2909, the smallest area was found at the green stage, as well as for F3060, which did not differ only at the green-yellow stage.

In the present study, the epidermal cell area increased from yellow-red to red stages for IT761, U2006 and TC2736, from green to yellow-green stages for CVR2909 and from yellow-green to yellow-red for F3060.

Hammami and Rapoport [8] evaluated different growth stages in olive and observed that epidermal cell area and height increased linearly with fruit size, while epidermal cell width reduced, which corroborates with results found in the present study. Although the cellular activity of the epidermis is considered a relevant component for fruit development, it has generally not been taken into account in fruit growth studies, but rather its importance of fruit interaction with environmental factors [6, 32].

According to Casado [33], width, height, perimeter and cell area are indicators of the size and morphology of epidermal cells.

The tomato processing epidermis is composed of small cells hermetically sealed in the outer layer. The surface of tomato fruits is smooth and waxy, which reduces friction between fruits and other surfaces.

The hypodermis is under the epidermis, with three to four layers of colenchyma cells, which contribute to resistance of tomato epidermis [34], which was also observed in fruits of this research (Figure 2A, C and D). However, other authors consider all cells below the epidermis as subepidermal parenchyma7.

In green tomato, well-defined parenchyma cell walls are observed (Figure 2A, B and C); in green-yellow fruits, cell integrity was verified (Figure $2 \mathrm{D}$ and $\mathrm{E}$ ); in red-yellow fruits, cellular integrity was also verified (Figure $2 \mathrm{~F}$ ); but at the red maturation stage, when fruits are fully ripe, the cell walls of parenchyma cells began to collapse (Figure $2 \mathrm{G}$ and $\mathrm{H}$ ).

The cellular characteristics of tomato are important for the understanding of injuries that occur to fruits. Colenchyma cells are more elastic, smaller, and have thicker wall, which resist more to forces applied than parenchyma cells, commonly interpreted as being structurally specialized as a tissue support [35]. While colenchyma cells have primary wall with irregular thickening, rich in pectin, which have the function of supporting growing parts [36], parenchyma cells are larger and comparatively have thinner walls, as can be seen in Figure 2F.

Colenchyma cells exhibit smaller intercellular spaces and thicker walls (Figure 2D), which makes them more resistant to compression, combining tensile strength with flexibility and plasticity [37]. Parenchyma is a metabolically active tissue, with air-filled spaces in the corners of cells. Intercellular spaces may be relatively large, which reduces cell-to-cell contact, thus weakening the tissue, resulting in areas vulnerable to damage by external forces [36], which can be observed in Figure 2F.

Small cells near the epidermis correspond to the region where cell divisions occur [38], as can be seen in Figures $2 \mathrm{C}$ and $\mathrm{D}$. Fruit epidermis does not present stomata, and cuticle thickness increases with fruit growth until maturation begins [39] (Figure 2B).

The mesocarp of fruits (me in Figure $2 A$ and $B$ ) is composed of large cells with thin walls and vascular bundles ( $\mathrm{fv}$ in Figures. 3A, B and C), which are connected to the vascular tissue of the peduncle [40]. The vascular bundles of tomatoes are centralized in the mesocarp, and cells close to them are isodiametric and smaller. Bundles are of fundamental importance for fruit development and quality, especially fleshy ones, since they carry water, minerals and photoassimilates, which compose them $[41,42,43]$.

The growth of fleshy fruits involves a balance between the supply of water by roots through vascular tissue and losses with transpiration through air organs (leaves and fruits) [44,45], affecting fruit resistance 
during post-harvest operations. Endocarp is a single-celled layer at the border of the locular cavity Figure $3 \mathrm{E}$. Septa divide locular cavities, filled with placental tissue and attached seeds [39].

According to Gillaspy and coauthors [46], tomato growth and development can be divided into four phases, and the latter occurs when fruits reach their final size, are still green and have most of their final mass, but small development still occurs during maturation, when starch is converted into carbohydrates [47] and color change from green to orange and finally to red [48].

Simultaneously with color changes, metabolic changes also occur, disintegration of the inner and central layers of the carpel, and placental tissue softens, as a consequence of the enzymatic degradation of cell walls, which become gelatinous. As opposed to Gillaspy and coauthors [46], Colombié and coauthors [49] distinguish the development of tomato fruit into three major periods: cell division, growth and maturation phase, the first two are important in determining the final fruit size, and in this study, only growth and maturation were observed.

Starch granules accumulate in cells when the synthesis rate exceeds the degradation rate (Luengwilai and Beckles) [50]. Thus, the starch content of tomatoes depends on maturation, cultivar and ripening conditions. Yu and coauthors [51] studied the composition of tomato fruits at different maturation stages and observed that starch accumulates until the yellow-green phase, then decreased rapidly, which was also observed in the present study. The starch content is very low in the last maturation stage [52]. In the present study, the presence of starch was not observed at the red stage, the last maturation stage.

The mechanism through which the starch granule is degraded during fruit development is unknown; it is known that the mechanism is complex, with action of interconnected enzymes [53], but this knowledge is of commercial interest, because these metabolic processes can influence the sugar availability in the fruit. In addition, if the starch granule is degraded during its synthesis, the tomato fruit may offer a new insight into this process [50]. However, Luengwilai and coauthors [54] suggest that starch synthesis or degradation can be regulated differently among cultivars, which was observed in the present study through anatomical analysis. Starch accumulation in green fruits may be one of the many factors that contribute to the pool of sugars in ripe fruits.

\section{CONCLUSION}

The photomicrographs analysis and statistical tools were effective to evaluate the epidermal tissue of different tomatoes to processing at different maturation stages and to choose that with morphological characteristics of the epidermis region more appropriate for the bulk transport. Tomato cuticle undergoes a thickening process during fruit growth and reduction at full fruit maturation. Cuticle deposition ends before full fruit maturation, resulting in a decrease in the amount of cutin per surface unit, and therefore, there is a decrease in cuticle thickness in the ripe fruit. Cuticle thickness is a good parameter of tomato quality in order to understand the fruit resilience to various stressors. The characteristics observed in the mesocarp of tomato fruits clearly showed the disruption of the cell wall during the fourth maturation stage of cells related to loss of firmness. Among the new genetic materials, F3060 has a greater potential to become cultivated for industrialization due to its morphological characteristics, such as elevated cuticle thickness and high values for width, height, perimeter and area of epidermal cells in full maturation stage, which make it suitable for bulk transport.

Funding: This research received no external funding.

Acknowledgments: The authors would like to thank IFG (Federal Institute of Goiás) for granting a license for improvement and a qualification scholarship for servers (PIQS) for the first author. To the company Cargill for the solicitude to serve us and for the cordial welcome in its dependencies and availability of material for analysis. To UFG (Federal University of Goiás) for the support and infrastructure provided for the development of this research.

Conflicts of Interest: The authors declare no conflict of interest.

\section{REFERENCES}

1. Trebolazabala J, Maguregui M, Morillas H, Diego A, Madariaga M. Portable Raman spectroscopy for an in-situ monitoring the ripening of tomato (Solanum lycopersicum) fruits. Spectrochim acta Part A Mol biomol spectrosc. 2017 Jun; 180(1): 138-143. doi.org/10.1016/j.saa.2017.03.024.

2. Sharma S, Uttam R, Bharti AS, Shukla N, Uttam KN. Label-Free Mapping of the Biochemicals in Tomato Fruit by Confocal Raman Microspectroscopy. Natl Acad Sci Lett. 2019 Feb; 42(4):1-4. doi.org/10.1007/s40009-018-07476.

3. Monfort AJ, Diaz A, Caño-Delgado A, Van Der Knaap E. The genetic basis of fruit morphology in horticultural crops: lessons from tomato and melon. J Exp Bot. 2014 Aug; 65(16):4625-37. doi.org/10.1093/jxb/eru017. 
4. Devaux MF, Bouchet B, Legland D, Guillon F, Lahaye M. Macro-vision and grey level granulometry for quantification of tomato pericarp structure. Postharvest Biol Technol. 2008 Feb; 47(2):199-209. doi.org/10.1016/j.postharvbio.2007.06.017.

5. Horiguchi G, Fujikura U, Ferjani A, Ishikawa N, Tsukaya $\mathrm{H}$. Large scale histological analysis of leaf mutants using two simple leaf observation methods: identification of novel genetic pathways governing the size and shape of leaves. Plant J. 2006 Oct;48(4): 638-44. doi.org/10.1111/j.1365-313X.2006.02896.x.

6. Fu FQ, Mao WH, Shi K, Zhou YH, Yu JQ. Spatio-temporal changes in cell division, endoreduplication and expression of cell cycle-related genes in pollinated and plant growth substances-treated ovaries of cucumber. Plant Biol. 2010 Dec;12(1):98-107. doi.org/10.1111/j.1438-8677.2009.00203.x.

7. Mintz-Oron S, Mandel T, Rogachev I, Feldberg L, Lotan O, Wang Z, Reinhard J, llya V, Avital A, Asaph A. Gene Expression and Metabolism in Tomato Fruit Surface Tissues. Plant Physiol. 2008 Jun;147(2):823-51. doi.org/10.1104/pp.108.116004.

8. Hammami SBBM, Rapoport HF. Quantitative analysis of cell organization in the external region of the olive fruit. Int J Plant Sci. 2012 Nov:173(9):993-1004. doi.org/10.1086/667610.

9. Galaz LG. (Development of the reticulate and cold damage in fruits of melon cultivars Cucumis melo L. Cantalupensis Group). Proyecto de Título. Santiago: Pontificia Universidad Católica de Chile; 2006.

10. Gastélum-Barrios A, Bórquez-López RA, Rico-García E, Toledano-Ayala M, Soto-Zarazú GM. Tomato quality evaluation with image processing: A review. Afr J Agr Res. 2011 May;6(14):3333-9. Doi.org/10.5897/AJAR11.108.

11. Combrink NJJ, Agenbag GA, Langenhiven P, Jacobs GA, Marais EM. Anatomical and compositional changes during fruit development of 'Galia'melons. S Afr J Plant Soil. 2001 Aug;18(1):7-14. doi.org/10.1080/02571862.2001.10634393.

12. Rocha RHC, Silva EO, Salomão LCC, Ventrella MC. Caracterização morfoanatômica do melão gália no ponto de colheita. Rev Bras Frutic. 2010 Jun; 32(2): 375-385. doi.org/10.1590/S0100-29452010005000048.

13. González Moreno A, Segado P, Quílez Al, Domínguez E, Heredia A. FTIR characterization of isolated fruit cuticles from tomato species. BMB - Contribuciones a congresos científicos. IHSM-UMA-CSIC, 2019 Apr. https://riuma.uma.es/xmlui/handle/10630/17496.

14. Reina-Pinto JJ, Yephremov A. Surface lipids and plant defenses. Plant Physiol Biochem. 2009 Jun; 47(6): 540549. doi.org/10.1016/j.plaphy.2009.01.004.

15. Javelle M, Vernoud V, Rogowsky PM, Ingran GC. Epidermis: the formation and functions of a fundamental plant tissue. New Phytol. 2010 Nov; 189(1): 17-39. doi.org/10.1111/j.1469-8137.2010.03514.x.

16. Albaloushi NNS, Azam MM, Eissa AHA. Mechanical properties of Tomato fruits under storage conditions. J Appl Sci. 2012 Jun; 86(6): 3053-64.

17. De Ketelaere B, Howart MS, Crezee L, Lammerty J, Viaen K, Bulens I, Baerdemaeker J. Postharvest firmness changes as measured by acoustic and low-mass impact devices: a comparison of techniques. Postharvest Biol Technol. 2006 Sep; 41(3): 275-84. doi.org/10.1016/j.postharvbio.2006.04.008.

18. Johansen D. Plant microtechnique. 1st ed. New York: McGraw-Hill Book Company; 1940. 523 p.

19. Schneider CA, Rasband WS, Eliceiri KW. NIH Image to ImageJ: 25 years of Image Analysis. Nat Methods. 2012 Jun; 9(7): 671-5. doi.org/10.1038/nmeth.2089.

20. Saladie M, Matas AJ, Isaacson T, Jenks MA, Goodwin SM, Niklas KJ, Lytovchenko A. A Reevaluation of the Key Factors That Influence Tomato Fruit Softening and Integrity. Plant Physiol. 2007 Jun; 144(2) 1012-28. doi.org/10.1104/pp.107.097477.

21. Bargel $\mathrm{H}$, Neinhuis $\mathrm{C}$. Tomato (Lycopersicon esculentum Mill.) fruit growth and ripening as related to the biomechanical properties of fruit skin and isolated cuticle. J Exp Bot. 2005 Feb; 56(413): 1049-60. doi.org/10.1093/jxb/eri098.

22. Goulao LF, Oliveira CM. Cell wall modifications during fruit ripening: when a fruit is not the fruit. Trends Food Sci Technol. 2008 Jan; 19(1): 4-25. doi.org/10.1016/j.tifs.2007.07.002.

23. Domínguez E, Heredia-Guerrero JA, Heredia A. The biophysical design of plant cuticles: an overview. New Phytol. 2011 Nov; 189(4): 938-49. doi.org/10.1111/j.1469-8137.2010.03553.x.

24. Dvir O, Farber I, Rom M, Rachman A, Beno-Moualem D, Meir S, Lichter A. Low humidity after harvest changes the abscission site in bunch cherry tomatoes. J Sci Food Agric. 2009 Apr; 89(9): 1519-25. doi.org/10.1002/jsfa.3618.

25. Lara I, Belge B, Goulao LF. The fruit cuticle as a modulator of postharvest quality. Postharvest Biol Technol. 2014 Jan; 87(1):103-12. doi.org/10.1016/j.postharvbio.2013.08.012.

26. Gibert C, Génard M, Vercambre G, Lescourret F. Quantification and modelling of the stomatal, cuticular and crack components of peach fruit surface conductance. Funct Plant Biol. 2010 May;37(3):264-74. doi.org/10.1071/FP09118. 
27. Dong X, Rao J, Huber DJ, Chang X, Xin F. Wax Composition of 'Red Fuji' Apple Fruit during Development and during Storage after 1-Methylcyclopropene Treatment. Hort Environ Biotechnol. 2012 Jul;53(4):288-97. doi.org/10.1007/s13580-012-0036-0.

28. Liu DC, Zeng Q, Ji QX, Li CF, Liu SB, Liu Y. A comparison of the ultrastructure and composition of fruits' cuticular wax from the wild-type 'Newhall' navel orange (Citrus sinensis [L.] Osbeck cv. Newhall) and its glossy mutant. Plant Cell Rep. 2012 Dec; 31(12): 2239-46. doi.org/10.1007/s00299-012-1333-x.

29. Kosma DK, Parsons EP, Isaacson T, Lü S, Rose JK, Jenks MA. Fruit cuticle lipid composition during development in tomato ripening mutants. Physiol Plant. 2010 Apr;139(1):107-17. doi.org/10.1111/j.1399-3054.2009.01342.x.

30. Konarska A. Morphological, histological and ultrastructural changes in fruit epidermis of apple malus domestica cv. ligol (Rosaceae) at fruit set, maturity and storage. Acta Biol Cravoviensia Ser Bot. 2014 Mar;56(2):35-58. doi.org/10.2478/abcsb-2014-0019.

31. Cao Y, Tang X, Giovannoni J, Xiao F, Liu Y. Functional characterization of a tomato COBRA-likegene functioning in fruit development and ripening. BMC Plant Biology. 2012 Nov;12(1):211-25. doi.org/10.1186/1471-2229-12-211.

32. Wang XG, Johnson MW, Daane KM, Yokorama VY. Larger olive fruit size reduces the efficiency of Psyttalia concolor, as a parasitoid of the olive fruit fly. Biol Control. 2009 Apr;49(1):45-51. doi.org/10.1016/j.biocontrol.2009.01.004.

33. Lopez-Casado G, Matas AJ, Dominguez E, Cuartero J, Heredia A. Biomechanics of isolated tomato (Solanum lycopersicum L.) fruit cuticles: the role of the cutin matrix and polysaccharides. J Exp. Bot. 2007 Nov; 58(14): 387583.doi.org/10.1093/jxb/erm233.

34. Hyodo H, Terao A, Furukawa J, Sakamoto N, Yurimoto H, Satoh S, Iwai H. Tissue Specific Localization of Pectin$\mathrm{Ca}^{2+}$ Cross-Linkages and Pectin Methyl-Esterification during Fruit Ripening in Tomato (Solanum lycopersicum). Public Libr Sci. 2013 Nov; 8(11): e78949. doi.org/10.1371/journal.pone.0078949.

35. Cutler DF, Botha T, Stevenson DW. Plant anatomy: an applied approach: Artmed Editora; 2011. 312p.

36. Taiz L, Zeiger E. Plant Physiology Sunderland: Sinauer Associates; 2010. 690p.

37. Mitsuhashi-Gonzalez K, Curry EA, Fellman JK, Fellman JK, Pitts MJ, Clary CD. Harvesting by Peel Color to Reduce Bruising of 'Golden Delicious' Apples. Int J Fruit Sci. 2010 Jun; 10(2): 166-76. doi.org/10.1080/15538362.2010.492334.

38. Cheniclet C, Rong WY, Causse M, Frangne N, Bolling L, Carde JP, Renaudin JP. Cell Expansion and Endoreduplication Show a Large Genetic Variability in Pericarp and Contribute Strongly to Tomato Fruit Growth. Plant Physiol. 2005 Dec; 139(4):1984-94. doi.org/10.1104/pp.105.068767.

39. Rančić D, Quarrie SP, Pećinar I. Anatomy of tomato fruit and fruit pedicel during fruit development. Microsc Sci Technol Appl and Educ. 2010 Oct;2(1):851-61.

40. Bussières P. Water import rate in tomato fruit: a resistance model. Ann Bot. 1994 Jan; 73(1):75-82. doi.org/10.1006/anbo.1994.1009.

41. Choat B, Gambetta GA, Shackel KA, Matthews MA. Vascular function in grape berries across development and its relevance to apparent hydraulic isolation. Plant Physiol. 2009 Nov;151(3):1677-87. doi.org/10.1104/pp.109.143172.

42. Zhang J, Liu Z, Ma H, Ma S. Studies on anatomy and distribution of the vascular bundles in the peach fruit. Acta Hortic Fruit. 2009 Jun;36(5):639-46.

43. Measham PF, Gracie AJ, Wilson SJ, Bound SA. Vascular flow of water induces side cracking in sweet cherry (Prunus avium L.). Adv Hort Sci. 2010 Jan;24(4):243-8.

44. Morandi B, Rieger M, Grappadelli L. Vascular flows and transpiration affect peach (Prunus persica Batsch.) fruit daily growth. J Exp Bot. 2007 Nov; 58(14): 3941-7. doi.org/10.1093/jxb/erm248.

45. Clearwater MJ, Luo Z, Ong SEC, Blattmann $P$, Thorp $T$. Vascular functioning and the water balance of ripening kiwifruit (Actinidia chinensis) berries. J EXp Bot. 2012 Mar; 63(5): 1835-47. doi.org/10.1093/jxb/err352.

46. Gillaspy G, Ben-Davi H, Gruissem W. Fruits: A Developmental Perspective. Plant Cell. 1993 Oct;5(10):1439-51. Doi.org/10.1105/tpc.5.10.1439.

47. Wang F, Sanz M, Brenne ML, Smith A. Sucrose synthase, starch accumulation, and tomato fruit sink strength. Plant Physiol. 1993 Jan;101(1):321-7. doi.org/10.1104/pp.101.1.321.

48. Carrari F, Fernie AR. Metabolic regulation underlying tomato fruit development. J Exp Bot. 2006 Jan;57(9):188397. doi.org/10.1093/jxb/erj020.

49. Colombié S, Nazaret C, Bénard C, Biais B, Mengin V, Solé M, Gibon Y. Modelling central metabolic fluxes by constraint-based optimization reveals metabolic reprogramming of developing Solanum lycopersicum (tomato) fruit. Plant J. 2015 Oct;81(1):24-39. doi.org/10.1111/tpj.12685.

50. Luengwilai K, Beckles DM. Starch granules in tomato fruit show a complex pattern of degradation. J Agric Food Chem. 2009 Aug;57(18):8480-7. doi.org/10.1021/jf901593m.

51. Yu MH, Olson LE, Salunkhe DK. Precursors of volatile components in tomato fruit-l.: Compositional Changes during development. Phytochem. 1967 Nov;6(11):1457-65. oi.org/10.1016/S0031-9422(00)82939-8. 
52. Tucker GA, Grierson D. Fruit ripening. The biochem of plant. 2013.12(1):265-81. 372p.

53. Liu H, Xie F, Yu L, Chen L, Li L. Thermal processing of starch-based polymers. Polymers Prog Polym Sci. 2009 Dec;34(12):1348-68. doi.org/10.1016/j.progpolymsci.2009.07.001.

54. Luengwilai K, Fiehn E, Beckles DM. Comparison of leaf and fruit metabolism in two tomato (Solanum lycopersicum L.) genotypes varying in total soluble solids. J Agr Foog Chem. 2010 Oct;58(22):11790-800. doi.org/10.1021/jf102562n.

(C) 2020 by the authors. Submitted for possible open access publication under the terms and conditions of the Creative Commons Attribution (CC BY NC) license (https://creativecommons.org/licenses/by-nc/4.0/). 